\title{
Adopting Digital Payment Based on the Features and Benefits Provided by the Application
}

\author{
Yanto Ramli
}

\begin{abstract}
Indonesia are facing the era of digitalization where almost all of the citizens today are using technology and digital. The development of information technology has been moving so fast including the payment of using digital system. This research is to analyze the variables of features and benefits towards customer's decision to use in relating to intention to use as the intervening variable. The data collection is done through distribution of questionnaire, where the population is consisted of the customers of Go-Pay digital payment application in Jakarta, Indonesia. This is a descriptive and verification research, the descriptive methods is based on assessment analysis and the verification methods is based on quantitative analysis. The sample determination is done through Purposive Sampling and the analysis technique is using Partial Least Square (PLS). The results show that features and benefits have positive and significant effect towards intention to use, the benefits of the application have the most significant influence towards intention to use compare to the features of the application. The results show that Go-Pay is the digital payment applications in Indonesia which is mostly used by the customers because of the features and benefits provided by the application, that is why Go-Pay is the most popular digital payment application used by the customers.
\end{abstract}

Index Terms-Features, Benefits, Intention to Use, Decision to Use.

\section{INTRODUCTION}

Indonesia are facing the era of digitalization where almost all of the citizens are using technology dan digital communications. The fast development of technology has influenced the lifestyles of the people and the technological developments have also changed the communication methods in carrying out their daily life activities. There have been a lot of changes due to these technologies development positively and negatively based on the benefit and advantages provided by these developments.

The development of information technology has brought about a lot of positive and negative changes and that has influenced the people daily activities. The innovations in technology have been developed to facilitate to support the community activities in almost every country. One of them is to bring in the digital payments to replace the physical money for the customer to pay their transactions. The purpose of this digital payment system is to make easier for customers to make purchases and transactions without bringing along the physical money. In terms of security, the digital payment system can also prevent robbery and theft of money.

Published on May 31, 2020.

Yanto Ramli, Universitas Mercu Buana, Indonesia.

(corresponding e-mail: yanto.ramli@mercubuana.ac.id)
According to Bank Indonesia Regulation (PBI) Number $20 / 6 / \mathrm{BI} / 2018$ that digital payment or electronic money in the provisions of Article 1 Paragraph 3 explain that "Electronic Money/digital payment is a payment instrument that meets the following elements: a). issued on the basis of the value of money paid in advance to the issuer; $b$ ). the value of money is stored electronically in a media server or chip; and c). the value of electronic money managed by the issuer is not a deposit as referred to the Act of governing banking (bi.go.id)."

Based on the support from the government, the increase of transactions through electronic money is triggered by the benefits provided by the digital payment, for both the society and the industry. Several other advantages are: (1) the convenience of payment transactions which is more quickly and safely, (2) the problem of cash handling is solved to minimize the risk of robbery and theft, (3) to help the central bank controlling printing of physical money. These are the reasons why government of almost all countries are pursuading and encouraging the people to used digital payment instead of physical money.

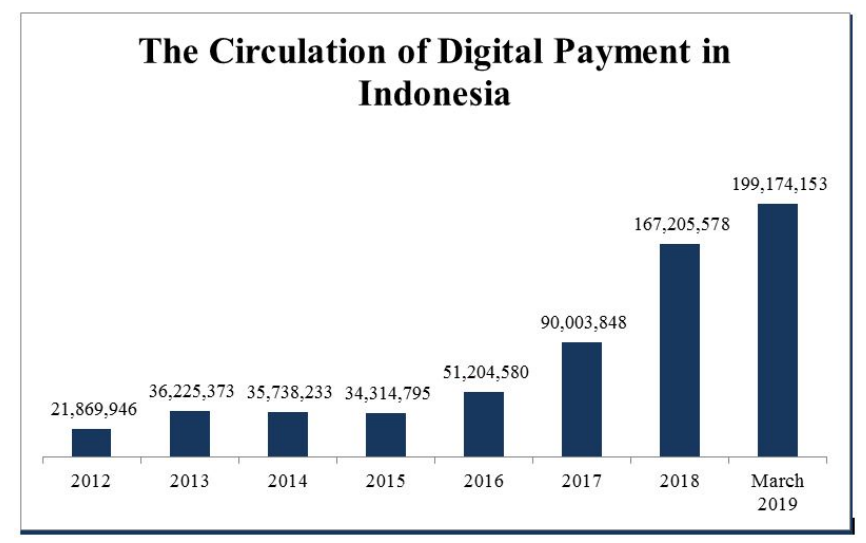

Fig. 1 The Circulation of Digital Payment in Indonesia (Source: bi.go.id (2019))

Electronic money as a digital payment instrument is increasingly used in Indonesia, this was supported by the data obtained from the statistics of the Bank of Indonesia (BI) in terms of the number of transactions done from digital payment from 2012-2019 as explained in the figure Above. In 2012, the number of digital payments in the circulation in Indonesia has reached $21,869,946$ transactions. Then in 2016, the number of transactions increased significantly to 51,204,580 transactions. And then in March 2019 the number continued to increase until it reached $199,174,153$ transactions. This shows that the use of digital payments in Indonesia continues to experience a significant increase. 


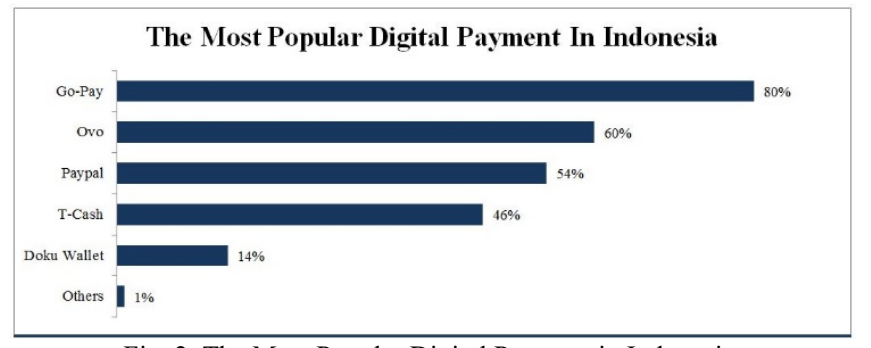

Fig. 2. The Most Popular Digital Payment in Indonesia Sumber: katadata.co.id

According to the results of the survey conducted by YouGov Indonesia in 2018, where Go-Pay digital payment application is the most popular digital payment application and are mostly used by the customer to pay their transactions. Based on the survey, $80 \%$ of the respondent prefer to choose Go-Pay as their digital payment application compare to Ovo Pay and Paypal as the second and third place after Go-Pay as shown in the figure above.

The intention of this research is to understand and find out the phenomenon about the increasing use of digital or cashless payments by the customers to pay for their transactions. The other reason is to understand how did GoPay lead the digital payments application and provide benefits to the customer so that customers have the intention to choose Go-Pay as their digital payment application compare to the rest of the digital payment application.

According to Ramli \& Soelton (2018) that all companies need to develop the ability to apply innovation in developing products and processes to be different from their competitors in order to provide products and services to the customers. Therefore, consumers may be able to distinguish and choose between products and services that provide different abilities and advantages.

\section{A. Research Gap}

Based on several discussions of previous studies, which according to Kartika \& Nugroho (2015) stated that the results of his research showed that the volume of electronic money transactions increased in ASEAN countries, while the circulation of physical money decreased dramatically. Wulandari et al (2016) examined the intensity of electronic money use, transaction volume, preferences, and perceptions about the use of electronic money in Malang. Vlasov (2017) concluded that cryptocurrency has several advantages when compared to other forms of money. Saraswati and Muklis (2018) explained that credit cards and e-money had a positive effect compared to debit cards in currency demand in Indonesia. Nugroho et al (2018) conveyed in their research that attitudes, subjective norms and behavioral control have a positive influence on consumer interest in using electronic money. Khalaf (2018) electronic money is the latest discovery of payment methods which is a major challenge faced by the central bank in handling financial policies. O'Dwyer (2019) in his research explained that the status of money as a memory technology is very important in reminding the role played by information and communication technology in economic transactions. Islam \& Baten (2019) concluded that the requirements of sophisticated technology infrastructure must have safe and user-friendly software with high-speed internet services identified as the main challenge to e-money in the future.
Based on the results of studies of from several previous studies on the digital payments application, it was revealed that most of the research are analysing more on the theoretically side that show the research gap, in this research the author will put more efforts on the empirical study based on the field observations and the methodological study based on the constructed variables of features, benefits, decision to use and intention to use, where generally from the research more theoretically explained which is a research gap that can be found, so the author feel the need to conduct research and study empirically through a methodology of the interest in using electronic payment applications about features and the benefits of the application where the customers might choose to use compare to the rest of the applications.

\section{LITERATURE REVIEW}

\section{A. Features}

Kotler \& Armstrong (2016: 262) states that features are one of the competitive tools to differentiate a company's products compared to its competitors' products. Being first to introduce valuable new features is one of the most effective ways to compete. Du et al (2015) explain that the idea of many factors is beyond the control of marketers and can cause a relative shift in the interests of various product features in shaping consumer purchasing decisions. This shift can change the relative attractiveness of products with different levels of features.

\section{B. Benefits}

Rekarti \& Hertina (2014) explained that the perception of benefits is something that states individuals believe that the use of a particular technology will improve the performance of individuals. Perceived benefits are perceptions of usefulness defined as a measure where the use of a technology is believed to bring benefits to those who use it. Kotler \& Keller (2016: 282) explained that business market segments can be divided into several variables used in the consumer market, such as geography, the benefits sought, and the level of usage for consumers, but business marketers also sometimes use other variables.

\section{Intention to Use}

Rekarti \& Hertina (2014) explained that interest in using is intention, generally defined as a deep desire to do something that is preferred. An individual who knows information about an online site can make him interested to do something related to which causes a sense of interest. According to Kotler \& Armstrong (2016: 185) that consumers can form purchase and use interests based on factors such as expected income, expected prices, and expected product benefits. However, unexpected events can change your purchase and usage interests. As such, preferences and even interest in buying and using do not always result in actual purchasing and usage choices.

\section{Decision to Use}

Prasetyaningsih \& Astini (2016) explained that the decision to use is the next stage after the intention or desire to buy but the decision to use is not the same as the actual 
usage. Decisions to use by consumers vary greatly, some are simple and some are complex. According to Prasetyaningsih \& Astini in Kotler \& Keller (2009) stated that the decisionmaking process using can be divided into five stages, namely: problem recognition, information search, alternative evaluation, decision to use and behavioral use. According to Kotler \& Armstrong (2016: 183) that after seeing the influence that can affect buyers, marketers must look at how consumers make purchasing decisions. The buyer decision process consists of five stages: introduction of needs, information seeking, alternative evaluation, purchasing decisions, and post-purchase behavior. Marketers need to focus on the entire buying decision process rather than just focusing on the buying decision.

\section{E. Research Hypothesis and Framework}

\section{1) The influence of features towards intention to use}

$\mathrm{Du}$ et al (2015) explain that the idea of many factors is beyond the control of marketers and can cause a relative shift in the interests of various product features in shaping consumer purchasing decisions. Rekarti \& Hertina (2014) explained that interest in using is intention, generally defined as a deep desire to do something that is preferred. Thus, the hypotheses that can be formulated in this study are as follows:

$\mathrm{H}_{1}$ : The influence of features towards intention to use.

2) The influence of benefits towards intention to use

Kotler \& Keller (2016: 282) explained that business market segments can be divided into several variables used in the consumer market, such as geography, the benefits sought, and the level of usage for consumers, but business marketers also sometimes use other variables. Rekarti \& Hertina (2014) explained that interest in using is intention, generally defined as a deep desire to do something that is preferred. Thus, the hypotheses that can be formulated in this study are as follows:

$\mathrm{H}_{1}$ : The influence of benefits towards intention to use.

3) The influence of features towards decision to use

Du et al (2015) explain that the idea of many factors is beyond the control of marketers and can cause a relative shift in the interests of various product features in shaping consumer purchasing decisions. Prasetyaningsih \& Astini (2016) explained that the decision to use is the next stage after the intention or desire to buy but the decision to use is not the same as the actual usage. Thus, the hypotheses that can be formulated in this study are as follows:

$\mathrm{H}_{4}$ : The influence of features towards decision to use.

\section{4) The influence of benefits towards decision to use}

Kotler \& Keller (2016: 282) explained that business market segments can be divided into several variables used in the consumer market, such as geography, the benefits sought, and the level of usage for consumers, but business marketers also sometimes use other variables. Prasetyaningsih \& Astini (2016) explained that the decision to use is the next stage after the intention or desire to buy but the decision to use is not the same as the actual usage. Thus, the hypotheses that can be formulated in this study are as follows:

H3: The influence of benefits towards decision to use.

\section{5) The influence of intention to use towards decision to} use

Rekarti \& Hertina (2014) explained that interest in using is intention, generally defined as a deep desire to do something that is preferred. Prasetyaningsih \& Astini (2016) explained that the decision to use is the next stage after the intention or desire to buy but the decision to use is not the same as the actual usage. Thus, the hypotheses that can be formulated in this study are as follows:

$\mathrm{H}_{5}$ : The influence of intention to use towards decision to use.

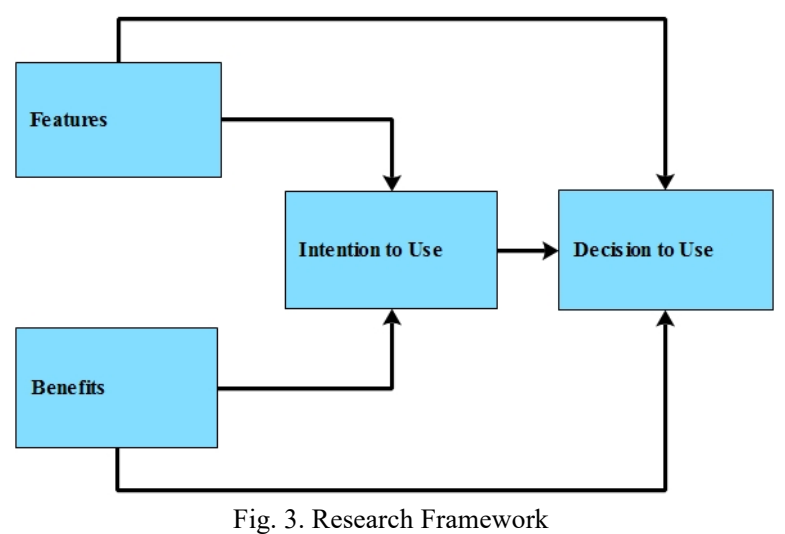

III. METHOD

The research designed in this study is using strategic marketing management approach that includes the operationalization variables, data collection method and information collection, defining the population, calculating the sample size and sampling techniques. The design of the analysis conducted in the testing research hypothesis is by conducting the study of the customers of Go-Pay digital payment application in Jakarta, Indonesia. This research begins with the preliminary research done through 30 customers as the respondent and follow by formulating constructs of the research variables.

The formulation and purpose of this study is to describe and reveal the interrelationship between the research variables explained above. This research is using descriptive and verification method with the type of causal investigation on the relationship and influence between the exogenous and endogenous variables.

The process of observation in this research is using time horizon with cross section/one shot, the collective data is obtained through the research done in 2020, the unit of the analysis is Go-Pay digital payment application located in Jakarta, Indonesia. The observation unit is the customers using Go-Pay digital payment application located around Jakarta. The design of analysis used is to test the hypothesis and to examine the relationship between the research variables by using Partial Least Square (PLS), one of the alternative method of structural analysis from Strutural Equation Modeling (SEM).

The validity testing was done by using the sample of 250 respondents randomly on the customers of Go-Pay digital payment application. The attempt of this validity testing is to find out the eligible of the selected items including the overall data collection process. 
The reliability test of this research data is using Cronbach's Alpha coefficient method. The Cronbach's Alpha coefficient is the reliability coefficient most commonly used because coefficient will indicate the variance of items with either correct or incorrect format such as Likert scale format. The Cronbach's Alpha coefficient is mostly used to evaluate internal consistency.

\section{RESUlts AND Discussion}

\section{A. Results}

The results of descriptive analysis conducted on the customer of Go-Pay digital payment application to find out the intention to use the digital payment based on the benefits and trust of the digital payment application. Based on the above-mentioned independent variable and then to find out the most significant influence of the variables towards the dependent variable of decision to use of the customers against the digital payment application.

The measurement model of analysis above showed the link between manifest variables (indicators) and each of the latent variables. The analysis of the measurement model is to test the validity and reliability of each of the dimensions and the indicators utilized to measure the variables constructed earlier. The analysis of the measurement model will describe the value of discriminant validity by looking at the value of square root of Average Variance Extracted (AVE) with the suggestion value above 0,5, loading factor $(>0.5)$, and constructed Composite Validity and Reliability (Cronbach's Alpha >0.70), are concluded that the dimensions and indicators are classified as reliable. As showed below:

TABLE I: GOODNESS OF FIT MODEL (GOF)

\begin{tabular}{lccccc}
\hline Variable & $\begin{array}{c}\mathbf{A V} \\
\mathbf{E}\end{array}$ & $\begin{array}{c}\text { Composite } \\
\text { Reliability }\end{array}$ & $\begin{array}{c}\text { Cronbach's } \\
\text { Alpha }\end{array}$ & $\begin{array}{c}\mathbf{R} \\
\text { Squa } \\
\text { re }\end{array}$ & $\begin{array}{c}\mathbf{Q} \\
\text { Squa } \\
\text { re }\end{array}$ \\
\hline Features & 0,5 & 0,857 & 0,911 & - & 0,64 \\
& 47 & & & & 1 \\
\hline Benefits & 0,6 & 0,936 & 0,921 & - & 0,51 \\
& 45 & & & & 6 \\
\hline Intention & 0,6 & 0,916 & 0,893 & 0,51 & 0,48 \\
to Use & 39 & & & 6 & 4 \\
\hline $\begin{array}{l}\text { Decision to } \\
\text { Use }\end{array}$ & 0,6 & 0,928 & 0,796 & 0,64 & 0,17 \\
\hline \hline
\end{tabular}

Source: From Data Processing (2020)

The value of $\mathrm{R}^{2}$ shows that the criterion is strong, with large $\mathrm{Q}$ value, this figure conclude that the propose model are supported by the empirical research classified as fit. Similarly, the value of AVE is $>0.5$, which indicate that all variables in the model are estimated to meet the cirteria of discriminant validity. The value of both Composite Reliability and Cronbach's Alpha for each of the variables are $>0.70$, which means that all the researched variables are classified as reliable and the outer model of this research is also classified as fit.

The result of measurement based on the data processing of model analysis on the dimensions indicates that the overall indicators which were processed above are classified as valid, as most of the value from the loading factors are greater than 0.70 .

The measurement model of latent variables against the dimensions explain the validity of the dimensions in order to measure the research variables. The following table shown below present the results of the measurement model analysis of each latent variable against the dimensions.

TABLE II: LOADING FACTOR BETWEEN LATENT VARIABLES AND DIMENSIONS

\begin{tabular}{|c|c|c|c|}
\hline Latent Variables-Dimensions & $\begin{array}{c}\text { Loadin } \\
g \\
\text { factor } \\
(\lambda) \\
\end{array}$ & $\begin{array}{c}\text { Standar } \\
\text { d Error } \\
\text { (SE) }\end{array}$ & $\begin{array}{c}\mathrm{T} \\
\text { Statisti } \\
\text { cs }(\mid \lambda \\
/ \mathrm{SE} \mid) \\
\end{array}$ \\
\hline Features $\rightarrow$ Diversity & 0.870 & 0.041 & 12.742 \\
\hline Features $\rightarrow$ Usability & 0.884 & 0,04 & 18.787 \\
\hline Features $\rightarrow$ Convenience & 0.880 & 0,033 & 19.523 \\
\hline Benefits $\rightarrow$ Ease & 0.763 & 0.041 & 16.976 \\
\hline Benefits $\rightarrow$ Advantage & 0.792 & 0.032 & 22.623 \\
\hline Benefits $\rightarrow$ Allocate & 0.786 & 0.037 & 21.486 \\
\hline Intention to Use $\rightarrow$ Expected Benefits & 0.825 & 0.052 & 25.654 \\
\hline Intention to Use $\rightarrow$ Expected Usability & 0.707 & 0.047 & 22.841 \\
\hline Intention to Use $\rightarrow$ Expected Profit & 0.877 & 0.043 & 22.451 \\
\hline Decision to Use $\rightarrow$ Need Recognition & 0.669 & 0.041 & 17.458 \\
\hline Decision to Use $\rightarrow$ Information Search & 0.528 & 0.052 & 25.425 \\
\hline $\begin{array}{l}\text { Decision to Use } \rightarrow \text { Evaluation of } \\
\text { Alternatives }\end{array}$ & 0.675 & 0.061 & 15.652 \\
\hline Decision to Use $\rightarrow$ Decision to Use & 0.684 & 0.045 & 13.326 \\
\hline $\begin{array}{l}\text { Decision to Use } \rightarrow \text { Post usability } \\
\text { Behavior }\end{array}$ & 0.714 & 0.049 & 15.269 \\
\hline
\end{tabular}

The results of the measurement model analysis of the research variables against the dimensions shows that almost all of the dimensions are valid with the value of $t$ count $>t$ table (2.01).

The estimated value for the path analysis in the structural model must be significant. This significant value can be obtained by the bootstrapping procedure. The significance of the hypothesis is by looking at the value of the parameter coefficient and the significance value of the T-statistics on the bootstrapping algorithm report. To find out the significant or insignificant is seen from the T-table at alpha $0.05(5 \%)=1.96$. Then, $\mathrm{T}$-tables are to compare with the Tcounts (T-statistics) as explained below.

TABLE III: THE RESULT OF HYPOTHESIS TESTING

\begin{tabular}{lccccc}
\hline \hline & $\begin{array}{c}\text { Original } \\
\text { Sample } \\
(\mathbf{O})\end{array}$ & $\begin{array}{c}\text { Sample } \\
\text { Mean } \\
(\mathbf{M})\end{array}$ & $\begin{array}{c}\text { Standard } \\
\text { Deviation } \\
(\text { STDEV })\end{array}$ & $\begin{array}{c}\text { T Statistics } \\
(\mid \mathbf{O} / \text { STDEV })\end{array}$ & $\begin{array}{c}\text { P } \\
\text { Values }\end{array}$ \\
\hline $\begin{array}{l}\text { Features: } \\
\text { Intention } \\
\text { to Use }\end{array}$ & 0,112 & 0,118 & 0,087 & 1,295 & 0,196 \\
\hline $\begin{array}{l}\text { Benefits: } \\
\text { Intention } \\
\text { to Use }\end{array}$ & 0,395 & 0,391 & 0,084 & 4,715 & 0,000 \\
\hline $\begin{array}{l}\text { Features: } \\
\text { Decision } \\
\text { to Use }\end{array}$ & 0,344 & 0,345 & 0,070 & 2,948 & 0,000 \\
\hline $\begin{array}{l}\text { Benefits: } \\
\text { Decision } \\
\text { to Use }\end{array}$ & 0,120 & 0,117 & 0,061 & & \\
\hline $\begin{array}{l}\text { Intention } \\
\text { to Use: } \\
\text { Decision } \\
\text { to Use }\end{array}$ & 0,144 & 0,144 & 0,079 & 1,967 & 0,050 \\
\hline \hline
\end{tabular}




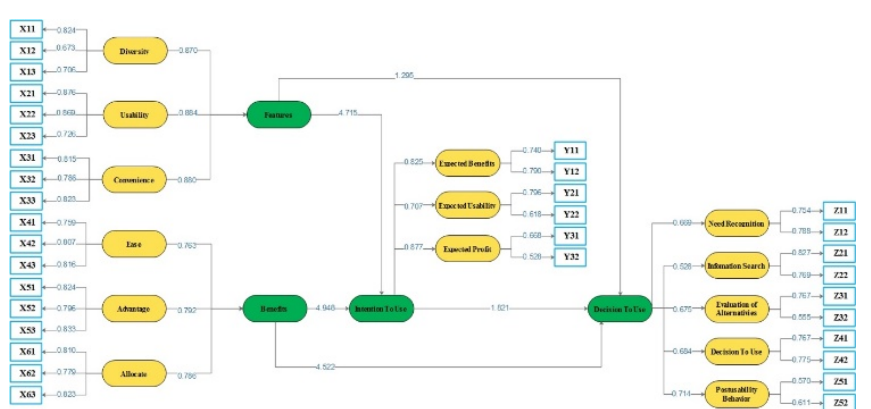

Fig. 4. Hypotesis Testing Source: From Data Processing (2020)

From the results of hypothesis testing, it was revealed that benefits has the highest influence on intention to use compared to features. Benefits also has the highest influence against decision to use rather than features. While intention to use is an important factor in determining the effect of decision to use.

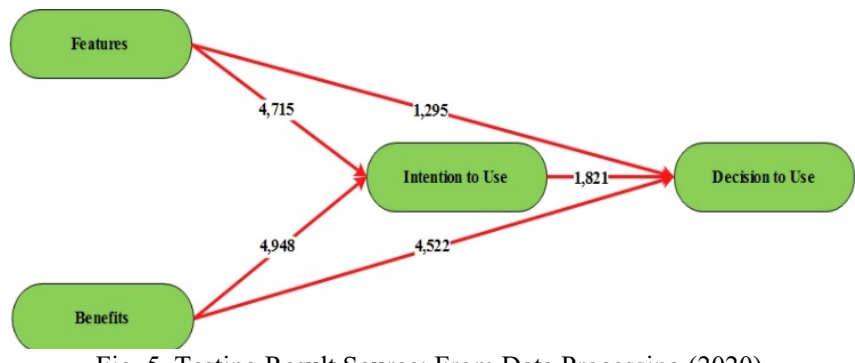

Fig. 5. Testing Result Source: From Data Processing (2020)

Based on the testing results above, the research variables indicate that benefits have the most significant influence on intention to use as the intervening variable with the figure of 4,948 , compare to variable of features with the figure of 4,715 . The direct effect of customer benefits also contributes higher influence towards decision to use with the figure of 4,522 compare to the direct effect of variable of features with the figure of 1,295 . Intention to use as the intervening variable also has a positive effect on decision to use with the figure of 1,821 which means the intervening variable has a significant effect on the decision to use of Go-Pay digital payment application.

\section{B. Discussion}

\section{1) The influence of features towards intention to use}

Based on the testing results, it shows that features has a positive and significant influence towards intention to use. The results of the analysis show that the T-statistic value is 4,715 with the original sample 0,112 . The $\mathrm{Y}$-statistics value is larger than the T-table 1,96 and original sample is positive which means that the customer of Go-Pay has the intention to use based on the features offered by Go-Pay digital payment application.

\section{2) The influence of benefits towards intention to use}

Based on the testing results, it shows that benefits has a positive and significant influence towards intention to use. The results of the analysis show that the T-statistic value is 4,948 with the original sample 0,324 . The $\mathrm{Y}$ statistics value is larger than the T-table 1,96 and original sample is positive which means that the customer of Go-Pay has the intention to use based on the benefits offered by Go-Pay digital payment application.

\section{3) The influence of features towards decision to use}

Based on the testing results, it shows that features has a positive and significant influence towards decision to use. The results of the analysis show that the T-statistic value is 1,295 with the original sample 0,166 . The Y-statistics value is larger than the T-table 1,96 and original sample is positive which means that the customers of Go-Pay has decided to use based on the features offered by Go-Pay digital payment application.

\section{4) The influence of benefits towards decision to use}

Based on the testing results, it shows that benefits has a positive and significant influence towards decision to use. The results of the analysis show that the T-statistic value is 4,522 with the original sample 0,299 . The Y-statistics value is larger than the T-table 1,96 and original sample is positive which means that the customers of Go-Pay has decided to use based on the benefits offered by Go-Pay digital payment application.

\section{5) The influence of intention to use towards decision to use}

Based on the testing results, it shows that intention to use has a positive and significant influence towards decision to use. The results of the analysis show that the T-statistic value is 1,821 with the original sample 0,248 . The $\mathrm{Y}$ statistics value is larger than the T-table 1,96 and original sample is positive which means that the customers of GoPay has decided to use based on Go-Pay digital payment application.

\section{CONCLUSION, IMPLICATION AND LiMitATION}

\section{A. Conclusion}

The research hypothesis constructed from this study is based on the four research variables: features and benefits as the independent variables, decision to use as the dependent variable and intention to use as the intervening variable. Based on the results of the above framework, it can be concluded that benefits has the highest influence on intention to use compare to variable of features. Benefits also has the highest influence directly to decison to use compare to the variable of features.

The objectives of this research is to find out how does the Go-Pay digital payment application attract the customers to chooses their application compare to the rest of the compatitors. This research has constructed four researched variables to find out the intention to use of the digital payment application.

Based on the hypothesis testing, it can be concluded as follows:

1. Customers choose Go-Pay digital payment application as their digital payment because of the various benefits offer by the application and avoid using cash payment.

2. Customers understand that Go-Pay payment application can be use to pay many types of transactions offer in the application.

3. Customers also realize that Go-Pay payment application has been working together with a lot of merchants for transactions. 
4. Customers also have been using the application and understand the features of the application that are easily apply.

5. The finding also show that Go-Pay digital payment application continues to innovate based on the customer requirements.

\section{B. Implication}

The study of this research has generated several theoretical and practical implications such as:

1. The constructed variables of features and benefits have positive and significant effect towards the intention to use of the digital payment application. This result has strengthened and enhance the amount of scientific literature within the scope of strategic marketing concept. The results show that strategic marketing concept can help to participate and contribute on the competitive advantage compare to the competitors.

2. The results of this study also indicate that the variables of features and benefits have positive and significant effect towards the decision to use of the digital payment application. This result has strengthened and enhance the amount of scientific literature within the scope of strategic marketing concept. The results show that strategic marketing concept can help the customer to choose and decide which application they are going to choose.

3. The results of this study also indicate that the variables of features and benefits have positive and significant effect towards the decision to use in relating to Go-Pay digital payment application. This result has strengthened and enhance the amount of scientific literature within the scope of strategic marketing management and also pointed out that applying strategic marketing is one of the ways to help how to compete with the competitors to win the competitions to acquire the competitive advantage of the company.

\section{Limitation}

This study is limited to analysing the customers who choose Go-Pay as their digital payment application. This research is also limited with the variable of features and benefits concerning the intention to use of the digital payment application, there might be further analysis of variables with a larger population coverage. There are further investigate that can be done concerning the advantage and disadvantages of the digital payment application and also the security of the system wise.

\section{REFERENCES}

Du, Rex Yuxing, Hu, Ye \& Damangir, Sina. (2015). Leveraging Trends in Online Searches for Product Features in Market Response Modeling. Journal of Marketing. Vol. 79, Page. 29-43.

Islam, Mohammad Saiful \& Baten, Md Azizul. (2019). Promoting FullFledged Electronic Money in South Asia: Evidence from Bangladesh. Business Perspective. Vol. 14, Issue 4. pp.166-182.

Kartika, Venna Tri \& Nugroho, Anggora Budi. (2015). Analysis on Electronic Money Transactions on Velocity of Money in ASEAN Countries. Journal of Business and Management. Vol. 4, No. 9. pp.1008-1020.

Khalaf, Hameed Hasan. (2018). The Impact of Electronic Money on the Effectiveness of Monetary Policy. Academy of Entrepreneurship Journal. Vol. 24, Issue 3.

Kotler, Philip \& Armstrong, Gary. (2016). Principles of Marketing. Sixteenth Edition. Pearson Education Limited. England.

Kotler, Phillip \& Keller, Kevin L. (2016). Marketing Management. Fifteenth Edition. Pearson Education Limited. England.

Nugroho, Anton, Najib, Mukhamad, and Simanjuntak, Megawati. (2018). Factors Affecting Consumer Interest in Electronic Money Usage with Theory of Planned Behavior. Journal of Consumer Sciences. Vol. 3, No. 1 .

O'Dwyer, Rachel. (2019). Cache Society: Transactional Records, Electronic Money, and Cultural Resistance. Journal of Cultural Economy. Vol. 12, Issue 2.

Peraturan Bank Indonesia Nomor 20/6/PBI/2018 Tentang Uang Elektronik. (2018). Diakses April 25 2019, dari bi.go.id: https://www.bi.go.id/id/ peraturan/sistem-pembayaran/Documents/PBI-200618.pdf

Prasetyaningsih, Erlita \& Astini, Rina. (2016). Pengaruh Citra Merek dan Gaya Hidup terhadap Keputusan Pembelian Produk Tas Branded Tiruan pada Wanita Karir Di Jakarta. Jurnal Ilmiah Manajemen dan Bisnis. Vol. 2, No. 2

Ramli, Yanto \& Soelton, Mochamad. (2018). Implementing Innovation Management on Market Attractiveness and Unique Resources to Enhance Business Performance on Organic Fertilizer Industries in Indonesia. Academy of Strategic Management Journal. Vol 17, Issue 2 .

Rekarti, Endi \& Hertina, Lilis. (2014). Beberapa Faktor yang berpengaruh terhadap Minat Beli Online pada Situs Jual Beli Tokobagus.com. Jurnal Ilmu Ekonomi dan Sosial. Jilid 2, Nomor 3.

Saraswati, Nurma \& Mukhlis, Imam. (2018). The Influence of Debit Card, Credit Card, and E-Money Transactions toward Currency Demand in Indonesia. Quantitative Economics Research. Vol. 1 No. 2.

Vlasov, Andrei V. (2017). The Evolution of E-Money. European Research Studies Journal. Vol. XX, Issue 1. pp. 215-224.

Wulandari, Dwi, Soseco, Thomas, Narmaditya, Bagus Shandy. (2016). Analysis of the Use of Electronic Money in Efforts to Support the Less Cash Society. International Finance and Banking. Vol. 3 No. 1.

https://www.bi.go.id/id/peraturan/sistem-pembayaran/Pages/PBI200618.aspx

https://www.google.com/search?q=uang+elektronik+terpopuler+di+indone sia + katadata\&safe $=$ strict\&client $=$ safari\&source $=$ lnms \& tbm $=$ isch\&sa $=$ X\&ved=2ahUKEwiK_Jb_yrTpAhXSV30KHSIKCEQ AUoAnoECAwQBA\&biw=1252\&bih=703\#imgrc=8OFzzbGDs LWDGM. 